\title{
Proteomics reveals potential non-neuronal cholinergic receptor-effectors in endothelial cells
}

\author{
Yuan-yuan ZHANG ${ }^{1}$, Wei SHEN ${ }^{1}$, Lian-cheng ZHANG ${ }^{1}$, Zhi-yuan PAN ${ }^{1}$, Chao-liang LONG ${ }^{1}$, Wen-yu CUI ${ }^{2}$, Yan-fang ZHANG ${ }^{1}$, \\ Hai WANG ${ }^{1,2, *}$ \\ ${ }^{1}$ Cardiovascular Drug Research Center, Institute of Health and Environmental Medicine, Academy of Military Medical Sciences, Beijing \\ 100850, China; ${ }^{2}$ Cardiovascular Drug Research Center, Thadweik Academy of Medicine, Beijing 100039, China
}

\begin{abstract}
Aim: The non-neuronal acetylcholine system (NNAS) in endothelial cells participates in modulating endothelial function, vascular tone, angiogenesis and inflammation, thus plays a critical role in cardiovascular diseases. In this study, we used a proteomic approach to study potential downstream receptor-effectors of NNAS that were involved in regulating cellular function in endothelial cells.

Methods: Human umbilical vein endothelial cells were incubated in the presence of acetylcholine, oxotremorine, pilocarpine or nicotine at the concentration of $10 \mu \mathrm{mol} / \mathrm{L}$ for $12 \mathrm{~h}$, and the expressed proteins in the cells were separated and identified with two-dimensional electrophoresis (2-DE) and LC-MS. The protein spots with the largest changes were identified by LC-MS. Biowork software was used for database search of the peptide mass fingerprints.

Results: Over 1200 polypeptides were reproducibly detected in 2-DE with a pH range of 3-10. Acetylcholine, oxotremorine, pilocarpine and nicotine treatment caused 16, 9, 8 and 9 protein spots, respectively, expressed differentially. Four protein spots were identified as destrin, FK506 binding protein 1A (FKBP1A), macrophage migration inhibitory factor (MIF) and profilin-1. Western blotting analyses showed that treatment of the cells with cholinergic agonists significantly decreased the expression of destrin, FKBP1A and MIF, and increased the expression of profilin-1.

Conclusion: A set of proteins differentially expressed in endothelial cells in response to cholinergic agonists may have important implications for the downstream biological effects of NNAS.
\end{abstract}

Keywords: non-neuronal acetylcholine system; endothelial cell; cholinergic agonist; destrin; FK506 binding protein 1A; macrophage migration inhibitory factor; profilin-1; proteomics; cardiovascular disease

Acta Pharmacologica Sinica (2014) 35: 1137-1149; doi: 10.1038/aps.2014.38; published online 4 Aug 2014

\section{Introduction}

Endothelial cells play a critical role in regulating vascular tone, angiogenesis, and vascular intimal inflammation ${ }^{[1]}$. Endothelial dysfunction is commonly observed in patients with atherosclerosis, hypertension, chronic heart failure, and other conditions, and has been recognized as a driving force in the development of cardiovascular diseases ${ }^{[2,3]}$. Targeting the endothelium to maintain endothelial function is considered to be a new strategy for prevention and therapy for several cardiovascular diseases ${ }^{[4-6]}$. Recently, evidence has indicated that the non-neuronal acetylcholine system (NNAS) described in endothelial cells participates in modulating the production and release of endothelial autacoids, eg, nitric oxide (NO) and prostaglandins, subsequently affecting cell function ${ }^{[7,8]}$. It has

\footnotetext{
* To whom correspondence should be addressed.

E-mail wh9588@sina.com

Received 2013-10-03 Accepted 2014-03-31
}

been shown that there are also two major types of cholinergic receptors in endothelial NNAs: the non-neuronal muscarinic receptors (NNMR) and non-neuronal nicotinic receptors $(\mathrm{NNNR})^{[9]}$. Acetylcholine, an endogenous agonist of both muscarinic receptors and nicotinic receptors, can induce endothelium-dependent vascular relaxation by enhancing the bioavailability of $\mathrm{NO}^{[10]}$. Despite that the so-called "endotheliumdependent vascular relaxation by acetylcholine" is used as a golden standard to measure endothelial function, the underlying physiological and/or pathophysiological role of NNAs in endothelial cells is still not fully understood. For example, it was well documented that stimulation of endothelial NNNRs with nicotine can induce endothelial dysfunction, vascular intimal inflammation, and accelerate atherosclerosis ${ }^{[11]}$. In contrast, treatment of the cholinergic system with acetylcholinesterase inhibitors, where the increased availability of acetylcholine stimulates two types of cholinergic receptors, significantly attenuates atherogenesis ${ }^{[12]}$. Therefore, it is unclear 
whether stimulation of endothelial NNAs is atherogenic or atheroprotective. Our previous studies showed that pharmacological characteristics of NNMRs were different from those of neuronal muscarinic receptors ${ }^{[13]}$. Pilocarpine, an agonist of nonselective neuronal muscarinic receptors, could not induce endothelium-dependent vascular relaxation ${ }^{[14]}$. However, another commonly studied muscarinic receptor agonist, arecoline, was able to stimulate NNMRs to produce endothelium-dependent vascular relaxation and to inhibit the development of atherosclerosis. Moreover, arecoline afforded potent protection against endothelial dysfunction induced by multiple atherogenic risk factors that contain high $D$-glucose and homocysteine ${ }^{[15-17]}$. The intracellular mechanism after activation of NNMRs that regulates signaling events to oppose risk factors that induce endothelial dysfunction is largely unknown. Therefore, it is essential to uncover the biological effectors after stimulation of NNAs in endothelial cells.

Proteomics is a discovery tool that allows previously unrecognized associations to be identified. It is a useful tool for studying the signal transduction mechanisms of cells and the effects of new drugs on cell function. In the present study, using two-dimensional gel electrophoresis (2-DE) and liquid chromatography/mass spectrometry (LC-MS ${ }^{[18,19]}$, we analyzed and identified the protein changes before and after stimulation with four different cholinergic agonists (acetylcholine bromide, oxotremorine, pilocarpine and nicotine) in cultured human umbilical vein endothelial cells (HUVECs). The four drugs used to treat the cells represent different agonists corresponding to different types of acetylcholine receptors (Table 1). Acetylcholine is able to activate the non-neuronal nicotinic and muscarinic receptors; oxotremorine can activate the nonneuronal muscarinic receptors but not non-neuronal nicotinic receptors; pilocarpine does not have the ability to activate nonneuronal nicotinic or muscarinic receptors; nicotine is another acetylcholine receptor agonist that activates only non-neuronal nicotinic receptors. We found sixteen, eight, eight and nine proteins changed after the stimulation of endothelial cells by acetylcholine, oxotremorine, pilocarpine and nicotine. In all of these proteins, Destrin, FKBP1A, MIF and Profilin-1 may have important roles in mediating downstream biological effects after stimulation of NNAs in endothelial cells. These data will contribute to a better understanding of the signaling events that are relevant to NNAs activation.

Table 1. Summary of the different types of acetylcholine receptors of the four different agonists.

\begin{tabular}{ccc}
\hline Drug & NNMR & NNNR \\
\hline ACh & + & + \\
Oxo & + & - \\
Pilo & - & - \\
Nico & - & + \\
\hline
\end{tabular}

ACh, Acetylcholine; Oxo, Oxotremorine; Pilo, Pilocarpine; Nico, Nicotine; NNMR, non-neuronal muscarinic receptor; NNNR, non-neuronal nicotinic receptor. +, activation; -, no activation.

\section{Materials and methods}

\section{Culture of human umbilical vein cells}

HUVECs were obtained from Cascade Biologics (Portland, OR, USA). Cells from the third to fourth passage were used for experiments. HUVECs were cultured in PMRI-1640 supplemented with $10 \%$ FBS and in a water-saturated atmosphere with $5 \% \mathrm{CO}_{2}$ at $37^{\circ} \mathrm{C}$ in a $75-\mathrm{cm}^{2}$ polystyrene culture flask. Full confluent HUVECs were digested with $0.25 \%$ trypsin for passage.

\section{Cell treatment and protein sample preparation}

Four cholinergic agonists, acetylcholine bromide (ACh), oxotremorine methiodide (Oxo), pilocarpine nitrate salt (Pilo) and (-)-nicotine hydrogen tartrate salt (Nico) were all purchased from Sigma-Aldrich (St Louis, MO, USA). The cells were incubated with ACh, Oxo, Pilo, and Nico at the concentration of $10 \mu \mathrm{mol} / \mathrm{L}$ for $12 \mathrm{~h}$. After treatment, the cells were digested with trypsin and washed three times with buffer solution (20 mmol/L Tris- $\mathrm{HCl}, \mathrm{pH} 7.5,250 \mathrm{mmol} / \mathrm{L}$ mannitol). After centrifugation at $1000 \times g$ at $4^{\circ} \mathrm{C}$ for $2 \mathrm{~min}$, the cells were resuspended in sample lysis buffer for $1 \mathrm{~h}$ with shaking. Then, the supernatant was obtained after centrifugation at $10000 \times g$ at $4^{\circ} \mathrm{C}$ for $1 \mathrm{~h}$ and directly applied to a $180-\mathrm{mm}$ immobilized $\mathrm{pH}$ gradient (IPG) strip for isoelectric focusing (IEF). Protein concentration was measured with a BCA protein assay kit (Pierce, Rockford, IL, USA), and the samples were stored at $-70^{\circ} \mathrm{C}$ until further use.

\section{Two-dimensional gel electrophoresis}

For IEF, $300 \mu \mathrm{g}$ of protein was mixed with a rehydration buffer containing $7 \mathrm{~mol} / \mathrm{L}$ urea, $2 \mathrm{~mol} / \mathrm{L}$ thiourea, 2\% (w/v) CHAPS, $0.3 \%(w / v)$ DTT, and $0.5 \%(v / v)$ IPG buffer up to $450 \mu \mathrm{L}$ total volume. This mixture was used to rehydrate the immobilized $24 \mathrm{~cm}$, linear Ready-Strip ${ }^{\mathrm{TM}}$ IPG Strips (pH 3-10, GE Healthcare, Piscataway, NJ, USA) for $12 \mathrm{~h}$ with a constant voltage $(30 \mathrm{~V})$ applied across the gel strips, which were placed in the IPGphor focusing tray. The rehydrated IPG gel strips were electrophoresed at $200 \mathrm{~V}$ for $1 \mathrm{~h}, 500 \mathrm{~V}$ for $1 \mathrm{~h}$, subjected to a linear voltage ramp from 1000 to $10000 \mathrm{~V}$ for $1 \mathrm{~h}$, and finally rapidly ramped up from $10000 \mathrm{~V}$ to a total of $60000 \mathrm{kVh}$. The maximum current was $50 \mu \mathrm{A}$ per gel strip.

After IEF, the IPG strips were placed in sodium dodecyl sulfate-polyacrylamide gel electrophoresis (SDS-PAGE) equilibration buffer containing $6 \mathrm{~mol} / \mathrm{L}$ Urea, $75 \mathrm{mmol} / \mathrm{L}$ Tris$\mathrm{HCl}$ (pH 8.8), 30\% glycerol, 2\% SDS, 1\% DTT for $15 \mathrm{~min}$. This procedure was repeated with SDS-PAGE equilibration buffer with $2.5 \%(w / v)$ iodoacetamide for an additional $15 \mathrm{~min}$. After equilibration, the IPG gel was transferred onto a $10 \%$ polyacrylamide gel and the second-dimension of electrophoresis (SDS-PAGE) was performed in the Ettan DALT six (GE Healthcare, USA), and performed at $1 \mathrm{~W}$ per gel for $1 \mathrm{~h}$, followed by $15 \mathrm{~W}$ per gel for $5 \mathrm{~h}$. Finally, silver staining of gels was performed as described previously ${ }^{[20]}$. Briefly, the gels were fixed for $30 \mathrm{~min}$ with $50 \%$ methanol containing $5 \%$ acetic acid. After several alternating washes of $50 \%$ methanol and water, the gels were sensitized by incubation in $0.2 \%$ sodium 
thiosulfate followed by several washes with water. The gels were incubated in $0.2 \%$ silver nitrate for 20 min followed by thorough rinsing with water. The gels were developed in $0.04 \%$ formalin in $2 \%$ sodium carbonate and the reaction was terminated with $5 \%$ acetic acid. For mass spectrometry-based identification, $1.5 \mathrm{mg}$ of protein was resolved by following the protocol used for large analytical gels, and the gels were then fixed with $50 \%$ ethanol containing 3\% phosphoric acid for $30 \mathrm{~min}$ and stained with $0.02 \%$ Coomassie Brilliant Blue (CBB)-G250, 3\% phosphoric acid, 17\% ammonium sulfate, and $34 \%$ ethanol. Relative molecular weights were determined by simultaneously running standard protein markers (PageRuler ${ }^{\mathrm{TM}}$ Prestained Protein Ladder Plus, \#SM0671, Fermentas). The isoelectric point (PI) values used were those given by the supplier of the immobilized $\mathrm{pH}$ gradient strips.

\section{Gel imaging and analysis}

Gels were digitally scanned using a LabScan scanner. Mell files of the gel images were transferred to a Sun Workstation for analysis with ImageMaster TM 2D Platinum software. Polypeptide spots in each gel image were delineated and the total intensity of pixels within each spot (the integrated intensity) was determined by the software. The integrated intensity of each spot was then expressed as a percent of the total integrated intensity over all spots within the region of analysis of the gel. This normalizes the amount of any given polypeptide spot to the largest possible number of polypeptides, and reports abundance as a relative value within each sample. The 2-DE analysis was performed for four replicates.

\section{Liquid chromatography-mass spectrometry (LC-MS) and data-} base search

Spots from the 2-DE gel were excised into approximately $1-\mathrm{mm}^{3}$ cubes, transferred into a microcentrifuge tube (Axygen, USA) and spun down on a bench-top microcentrifuge. The gel plugs were destained with $100 \mu \mathrm{L}$ of $100 \mathrm{mmol} / \mathrm{L}$ ammonium bicarbonate/acetonitrile $[1: 1(v / v)]$ and incubated with occasional vortexing for $30 \mathrm{~min}$. After destaining, $100 \mu \mathrm{L}$ of neat acetonitrile was added and incubated at room temperature with occasional vortexing until the gel pieces became white and shrunken. Then, gel pieces were reduced with 20 $\mathrm{mmol} / \mathrm{L}$ DTT at $56^{\circ} \mathrm{C}$ for $30 \mathrm{~min}$ and dehydrated with neat acetonitrile once before treatment with $55 \mathrm{mmol} / \mathrm{L}$ iodoacetamide in the dark for $20 \mathrm{~min}$ at room temperature. The gel pieces were again dehydrated with neat acetonitrile and enough trypsin buffer [approx $50 \mu \mathrm{L}, 13 \mathrm{ng} / \mu \mathrm{L}$ trypsin in 25 $\mathrm{mmol} / \mathrm{L}$ ammonium bicarbonate containing $10 \%(v / v)$ acetonitrile] was added to cover the dry pieces, allowing the buffer to be absorbed into the gel pieces at $4{ }^{\circ} \mathrm{C}$. The trypsin buffer was replenished if the buffer was completely absorbed into the gel to keep the gel pieces from drying. The tubes containing trypsin buffer were then placed into an air circulation thermostat and incubated overnight at $37^{\circ} \mathrm{C}$. When the digestion was completed, the gel pieces were extracted with $100 \mu \mathrm{L}$ of extraction buffer [1:2 $(v / v)$ of $5 \%$ formic acid/acetonitrile] for $15 \mathrm{~min}$ at $37^{\circ} \mathrm{C}$ in a shaker. The volume of extracted solution was reduced in a SpeedVac (Thermo Fisher, USA) to approximately $30 \mu \mathrm{L}$. The extracted solution of tryptic peptides from each of the gel pieces was analyzed by a LCQ Deca XP mass spectrometer (Thermo Electron Corp, CA, USA). Spectra of a survey scan followed by 5 CID events were recorded by mass spectrometry. The "peak list" was created automatically by the EXTRACTMS program provided in the Xcalibur software package (Bioworks v3.3). The $\mathrm{MS}^{2}$ spectra with a total ion current (TIC) higher than $10^{4}$ were used to search for matches against a maize protein sequence database ipi.HUMAN.v3.66. fasta (86867 entries) using the TurboSEQUEST algorithm. The search parameters were based on the TurboSEQUEST algorithm. The degree of completeness of the b- and y-ion series for each TurboSEQUEST result was manually checked for every protein identified.

\section{Western blotting analysis}

HUVECs cells treated with the four cholinergic agonists as described above were collected, and the proteins were extracted with a sample lysis buffer that includes a protease inhibitor cocktail (Roche, Germany). Protein concentration was determined with a BCA protein assay kit (Pierce, USA). Individual samples containing $20 \mu \mathrm{g}$ of protein from the control and each agonist-treated HUVECs cells were loaded onto a $12 \%$ SDS-PAGE gel and separated by electrophoresis, and then electrophoretically transferred onto pieces of PVDF membranes for Western blotting. The membranes were blocked with 3\% non-fat milk powder in TBST buffer $(\mathrm{pH}$ 7.6) composed of $150 \mathrm{mmol} / \mathrm{L} \mathrm{NaCl} ; 10 \mathrm{mmol} / \mathrm{L}$ Tris- $\mathrm{HCl}$ and $0.1 \%$ Tween-20 for $2 \mathrm{~h}$ at room temperature. Then, the membranes were incubated with specific primary antibodies against Destrin (Abcam, UK; ab95298, 1:500 dilution), FKBP1A (Thermo Scientific, USA; 1:200 dilution), Profilin-1 (Cell Signaling Technology, USA; 1:1000 dilution), or MIF (Abcam, UK; abab7207, 1:2000 dilution), in TBST (0.1\% Tween-20) containing $5 \%$ nonfat milk powder overnight at $4{ }^{\circ} \mathrm{C}$, or $1 \mathrm{~h}$ at room temperature. Then, membranes were washed three times with TBST buffer $(0.1 \%$ Tween-20) for $5 \mathrm{~min}$ each and incubated with horseradish peroxidase (HRP)-conjugated secondary antibody at dilution of 1:10 000 for $1 \mathrm{~h}$ at room temperature. After washing with TBST buffer, the chemiluminescence reaction in which HRP reacts with SuperSignal ${ }^{\circledR}$ West Pico Chemiluminescent substrate (Pierce, USA) was performed to detect signals. At the same time, GAPDH was used as a loading control to verify the amount and integrity of the whole proteins.

\section{Results}

Two-dimensional protein maps of endothelial cells stimulated by cholinergic agonists

In this work, we established the 2-DE protein patterns of the control group and the endothelial cells activated by ACh, Oxo, Pilo, and Nico. More than 1200 protein spots were detected on the 2-DE gels that showed similar protein patterns with silver staining of $300 \mu \mathrm{g}$ of total proteins. Figure 1 displays the overall 2-DE patterns of protein extracts of control/ACh (Figure 1A), control/Oxo (Figure 1B), control/Pilo (Figure 1C), and 
A
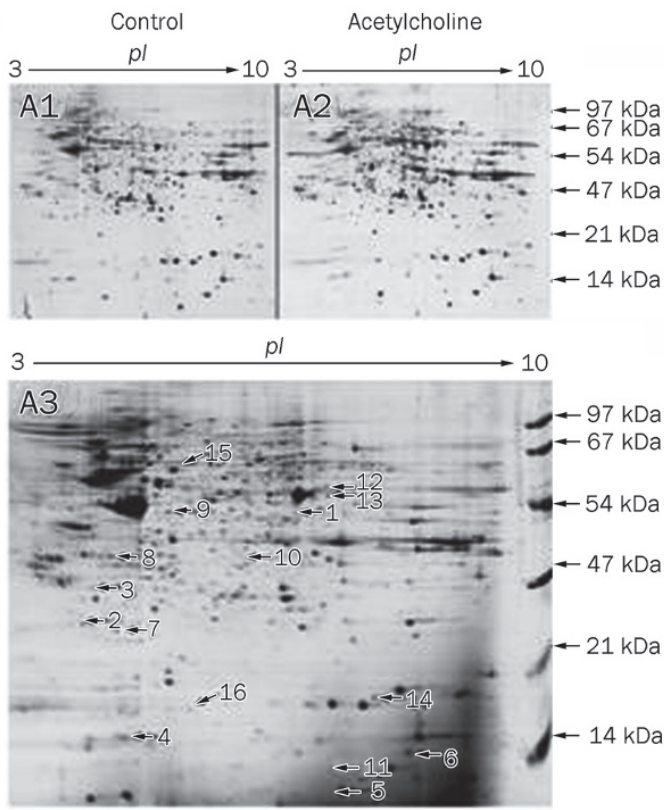

C
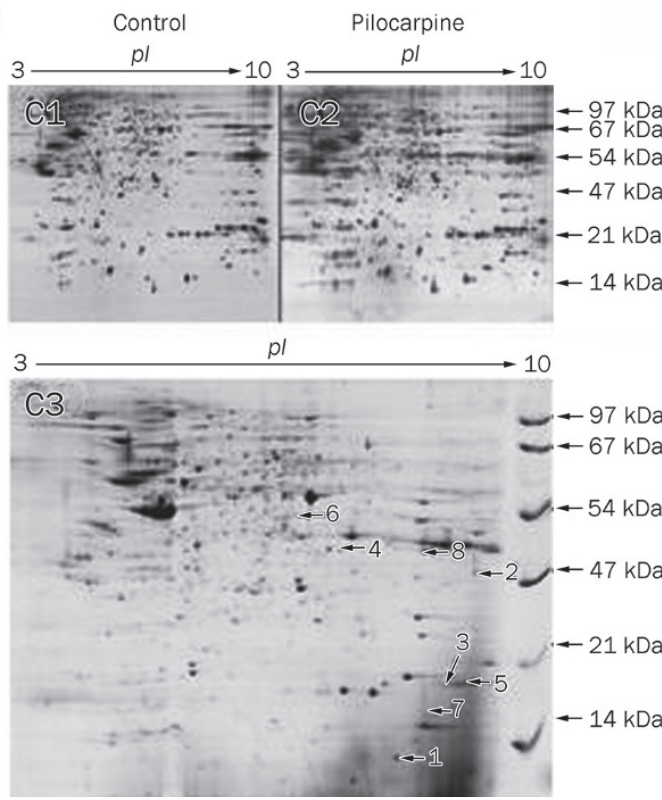

B
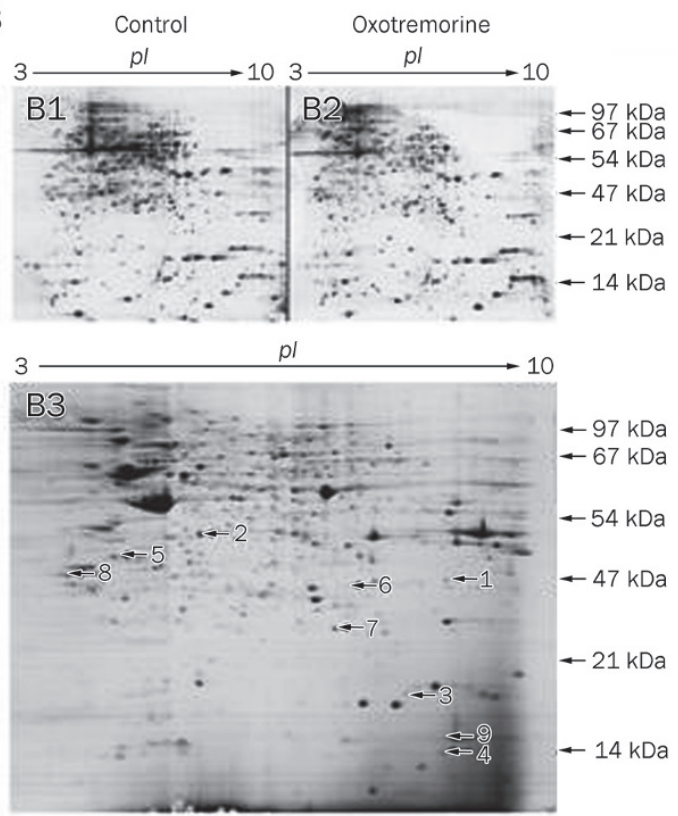

D
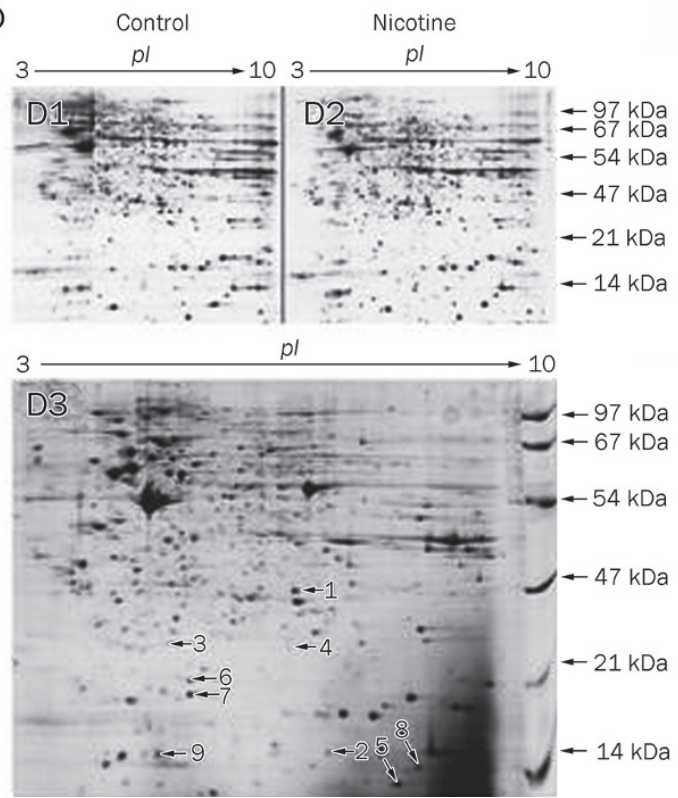

Figure 1A-1D. Two-dimensional gel showing the proteome of cultured HUVECs at a pH range of 3-10 after stimulation with cholinergic agonists. The cells were incubated with different agonists at pharmacological concentration of $10 \mu \mathrm{mol} / \mathrm{L}$ for $12 \mathrm{~h}$. Positions of the differentially expressed protein spots with corresponding spot numbers are indicated with arrows. These results are representative of at least four independent experiments. A1/A2: before/after acetylcholine treatment, protein maps were stained with silver; A3: differentially expressed spots between the control and acetylcholine group, spots in A3 were visualized with Coomassie Brilliant Blue staining. The expression-changed proteins with spot numbers were identified and they are listed in Table 2. B1/B2: before/after oxotremorine treatment, silver staining; B3: differentially expressed protein spots between control and oxotremorine, Coomassie Brilliant Blue staining. The expression-changed proteins with the spot numbers are listed in Table 3. C1/C2: before/after pilocarpine treatment, silver staining; C3: differentially expressed protein spots between control and pilocarpine, Coomassie Brilliant Blue staining. The protein expression changes with the spot numbers were listed in Table 4. D1/D2: before/after nicotine treatment, silver staining; D3: differentially expressed protein spots between control and nicotine, Coomassie Brilliant Blue staining. The protein expression changes with the spot numbers are listed in Table 5. (E-H) show magnified views of some differentially expressed proteins between the control and each acetylcholine receptor agonist treatment group. (E) differentially expressed proteins between the control and acetylcholine treatment group. (F) between the control and oxotremorine treatment group. $(\mathrm{G})$ between the control and pilocarpine treatment group. $(\mathrm{H})$ between the control and nicotine treatment group.

control/Nico (Figure 1D). Based on analysis with Image Master 2D Platinum software, among all the detected spots, 16, 8, 8 and 9 spots were separately changed in cells treated with ACh,
Oxo, Pilo and Nico, showing detectable changes above 2-fold and the match rate was above $60 \%$ (Figure 1E-1H). 
$\mathrm{E}$
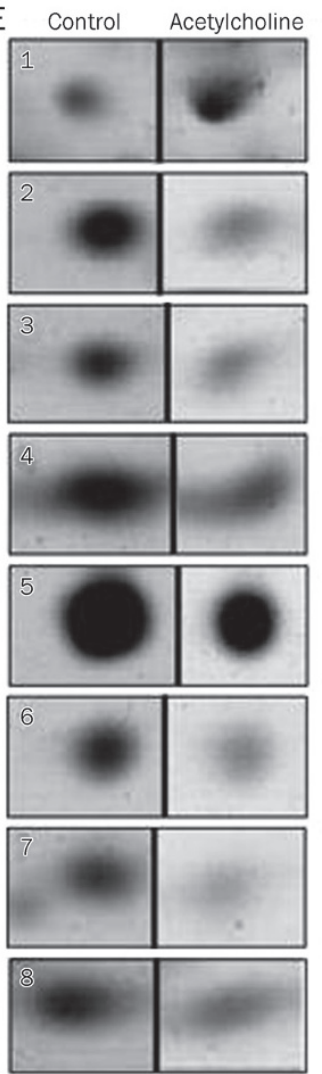

$\mathrm{F}$

Control Oxotremorine
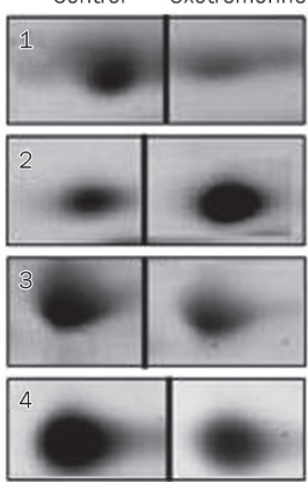

Control Acetylcholine
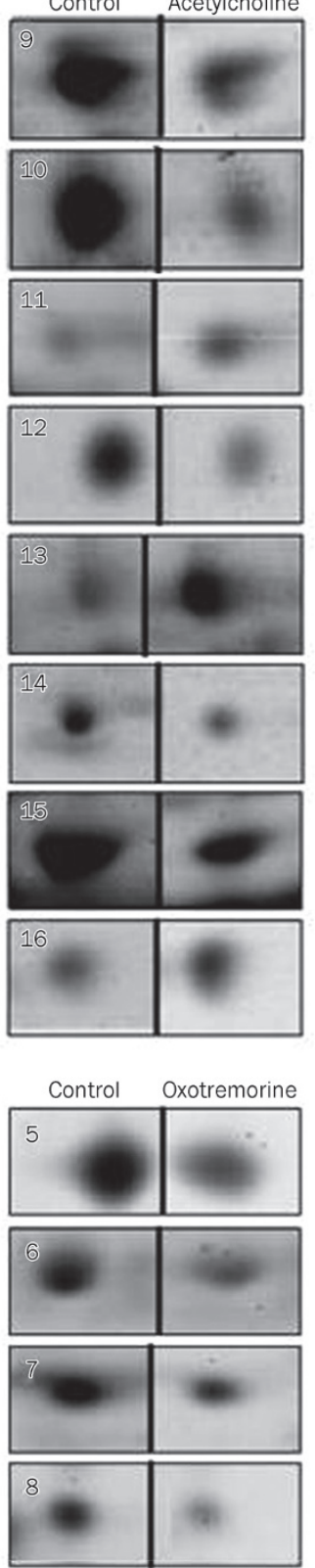

G
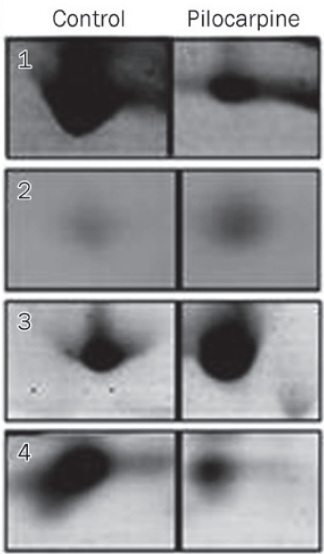

$\mathrm{H}$
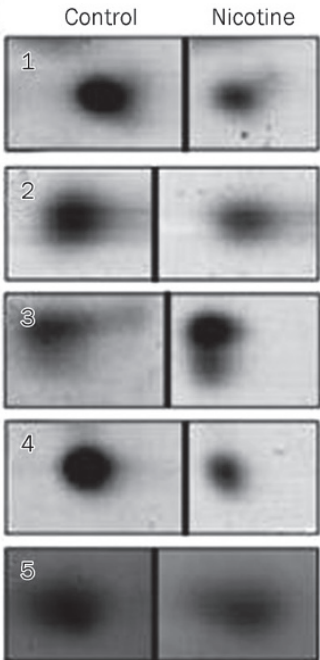
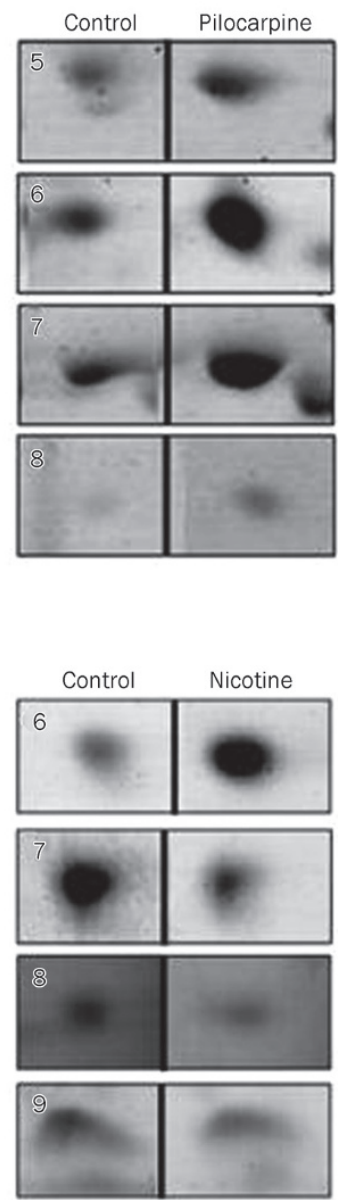

Figure 1E-1H. Two-dimensional gel showing the proteome of cultured HUVECs at a pH range of 3-10 after stimulation with cholinergic agonists. The cells were incubated with different agonists at pharmacological concentration of $10 \mu \mathrm{mol} / \mathrm{L}$ for $12 \mathrm{~h}$. Positions of the differentially expressed protein spots with corresponding spot numbers are indicated with arrows. These results are representative of at least four independent experiments. A1/A2: before/after acetylcholine treatment, protein maps were stained with silver; A3: differentially expressed spots between the control and acetylcholine group, spots in A3 were visualized with Coomassie Brilliant Blue staining. The expression-changed proteins with spot numbers were identified and they are listed in Table 2. B1/B2: before/after oxotremorine treatment, silver staining; B3: differentially expressed protein spots between control and oxotremorine, Coomassie Brilliant Blue staining. The expression-changed proteins with the spot numbers are listed in Table 3. C1/C2: before/after pilocarpine treatment, silver staining; C3: differentially expressed protein spots between control and pilocarpine, Coomassie Brilliant Blue staining. The protein expression changes with the spot numbers were listed in Table 4. D1/D2: before/after nicotine treatment, silver staining; D3: differentially expressed protein spots between control and nicotine, Coomassie Brilliant Blue staining. The protein expression changes with the spot numbers are listed in Table 5. (E-H) show magnified views of some differentially expressed proteins between the control and each acetylcholine receptor agonist treatment group. (E) differentially expressed proteins between the control and acetylcholine treatment group. (F) between the control and oxotremorine treatment group. $(\mathrm{G})$ between the control and pilocarpine treatment group. $(\mathrm{H})$ between the control and nicotine treatment group. 
Identification of differentially expressed proteins by LC-MS and database search

To further identify these differentially expressed proteins, while keeping the silver-staining gels as a reference, we excised the differentially expressed proteins from hot Coomassie blue stained 2-DE gels and digested them with trypsin. These markedly changed proteins were successfully identified by LC-MS. Several peptide mass fingerprints (PMF) were successfully obtained. A few of the selected PMFs are displayed in Figure 2. Database searches of all the PMFs were performed with Bioworks to identify the protein spots. The identified proteins in the ACh, Oxo, Pilo and Nico group are listed separately in Table $2-5$.
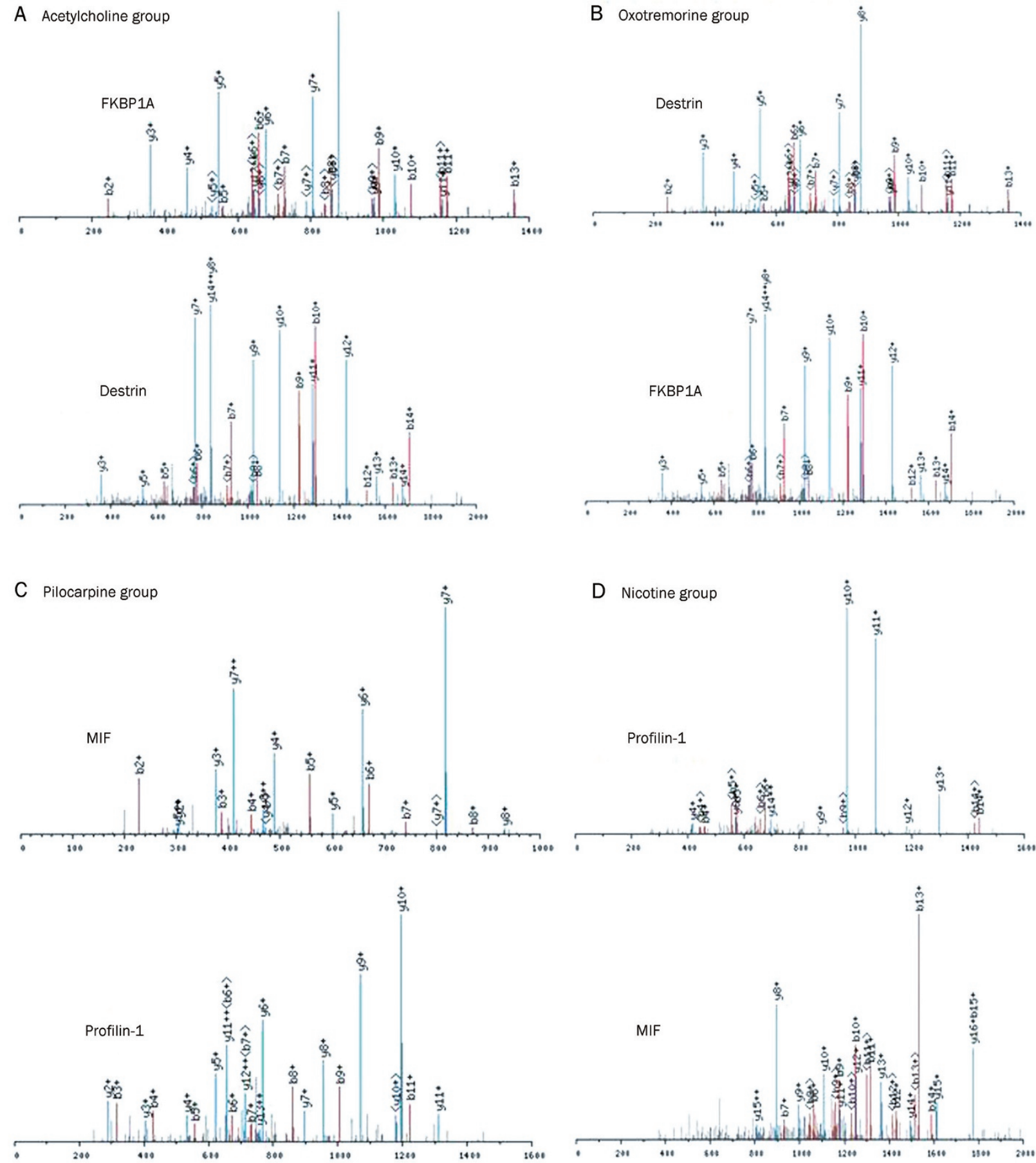

Figure 2. Peptide mass fingerprints of a few of selected protein spots obtained from MALDI-TOF-MS. (A) protein spot 6 (FKBP1A) and 14 (Destrin) from Figure 1A3. (B) protein spot 3 (Destrin) and 4 (FKBP1A) from Figure 1B3. (C) protein spot 1 (MIF) and 7 (Profilin-1) from Figure 1C3. (D) protein spot 1 (Profilin-1) and 4 (MIF) from Figure 1D3. 
Table 2. List of differentially expressed proteins found in the most significant network $12 \mathrm{~h}$ after acetylcholine treatment using Ingenuity Pathway Analysis (Figure 1A1-1A3). The proteins were identified by 2-DE and LC-MS. The spots identified by 2-DE are indicated with a corresponding number on the gel ( $\uparrow$, the tprotein up-regulated; $\downarrow$, the protein down-regulated).

\begin{tabular}{|c|c|c|c|c|c|c|c|}
\hline $\begin{array}{l}\text { Spot } \\
\text { № }\end{array}$ & Protein name & $\begin{array}{l}\text { Gene } \\
\text { names }\end{array}$ & Accession & $\mathrm{Mw}(\mathrm{kDa})$ & pl & Change & Protein function \\
\hline 1 & $\begin{array}{l}\text { Aspartate aminotransferase, } \\
\text { cytoplasmic }\end{array}$ & GOT1 & P17174 & 46116.31 & 6.57 & $\uparrow$ & $\begin{array}{l}\text { Plays a role in amino acid metabolism and the urea and } \\
\text { tricarboxylic acid cycles. }\end{array}$ \\
\hline 2 & $\begin{array}{l}\text { Tumor protein, translationally- } \\
\text { controlled } 1\end{array}$ & TPT1 & P13693 & 21525.66 & 5.34 & $\downarrow$ & Involved in calcium binding and microtubule stabilization. \\
\hline 3 & Calpain small subunit 1 & CAPNS1 & P04632 & 28315.71 & 5.05 & $\begin{array}{l}\mathrm{h} \\
\mathrm{t} \\
\mathrm{t}\end{array}$ & $\begin{array}{l}\text { Regulatory subunit of the calcium-regulated non-lysosomal } \\
\text { thiol-protease which catalyzes limited proteolysis of } \\
\text { substrates involved in cytoskeletal remodeling and signal } \\
\text { transduction. }\end{array}$ \\
\hline 4 & Galectin-1 & LGALS1 & P09382 & 14584.51 & 5.34 & ti & $\begin{array}{l}\text { Regulate apoptosis, cell proliferation and cell differentia- } \\
\text { tion. Binds beta-galactoside and a wide array of complex } \\
\text { carbohydrates. Inhibits CD } 45 \text { protein phosphatase activity } \\
\text { and therefore the dephosphorylation of Lyn kinase. }\end{array}$ \\
\hline 5 & Protein S100-A10 & S100A10 & P60903 & 11071.91 & 7.3 & $\begin{array}{l}\text { A } \\
\text { n } \\
\mathrm{s}\end{array}$ & $\begin{array}{l}\text { A regulator of protein phosphorylation in that the ANXA2 } \\
\text { monomer is the preferred target (in vitro) of tyrosine- } \\
\text { specific kinase. }\end{array}$ \\
\hline 6 & FKBP1A protein & FKBP1A & P62942 & 15688.97 & 9.26 & $\begin{array}{l}\mathrm{P} \\
(1+1 \\
\text { ir }\end{array}$ & $\begin{array}{l}\text { Plays a role in modulation of ryanodine receptor isoform-1 } \\
\text { (RYR-1); catalyzes the cis-trans isomerization of proline } \\
\text { imidic peptide bonds in oligopeptides. }\end{array}$ \\
\hline 7 & Lactoylglutathione lyase & GLO1 & Q04760 & 20646.52 & 5.12 & $\downarrow$ & $\begin{array}{l}\text { Catalyzes the conversion of hemimercaptal, formed from } \\
\text { methylglyoxal and glutathione, to S-lactoylglutathione. }\end{array}$ \\
\hline 8 & $\begin{array}{l}\text { Microtubule-associated protein } \\
\text { RP/EB family member } 1\end{array}$ & MAPRE1 & Q15691 & 29867.89 & 5.02 & It & $\begin{array}{l}\text { Involved in microtubule polymerization, and spindle } \\
\text { function by stabilizing microtubules and anchoring them at } \\
\text { centrosomes. May play a role in cell migration. }\end{array}$ \\
\hline 9 & Selenide, water dikinase 1 & SEPHS1 & P49903 & 42910.58 & 5.65 & $\downarrow$ & Synthesizes selenophosphate from selenide and ATP. \\
\hline 10 & $\begin{array}{l}\text { Phosphatidylinositol transfer } \\
\text { protein (PITP) alpha isoform }\end{array}$ & PITPNA & Q00169 & 31675.13 & 6.13 & $\downarrow$ & $\begin{array}{l}\text { Catalyzes the transfer of Ptdlns and phosphatidylcholine } \\
\text { between membranes. }\end{array}$ \\
\hline 11 & D-dopachrome decarboxylase & DDT & P30046 & 12580.57 & 7.25 & $\uparrow$ & $\begin{array}{l}\text { Tautomerization of D-dopachrome with decarboxylation to } \\
\text { give 5,6-dihydroxyindole (DHI). }\end{array}$ \\
\hline 12 & $\begin{array}{l}\text { Isoform } 1 \text { of platelet-activating } \\
\text { factor acetylhydrolase IB subunit } \\
\text { alpha }\end{array}$ & PAFAH1B1 & P43034 & 46506.78 & 7.03 & $\begin{array}{l}\mathrm{p} \\
\mathrm{p} \\
\mathrm{n} \\
\mathrm{r}\end{array}$ & $\begin{array}{l}\text { Required for proper activation of Rho GTPases and actin } \\
\text { polymerization at the leading edge of locomoting cerebellar } \\
\text { neurons and postmigratory hippocampal neurons in } \\
\text { response to calcium influx triggered via NMDA receptors. }\end{array}$ \\
\hline 13 & $\begin{array}{l}\text { Isoform mitochondrial of fumarate } \\
\text { hydratase, mitochondrial }\end{array}$ & $\mathrm{FH}$ & B1ANK7 & 45494.82 & 7.27 & $\uparrow$ & Fumarate hydratase activity; cell junction. \\
\hline 14 & Destrin & DSTN & P60981 & 18374.53 & 8.12 & A & $\begin{array}{l}\text { Actin-depolymerizing protein. Severs actin filaments } \\
\text { (F-actin) and binds to actin monomers (G-actin). Acts in a } \\
\text { pH-independent manner. }\end{array}$ \\
\hline 15 & Copine-1 & CPNE1 & Q99829 & 59058.79 & 5.52 & $\downarrow$ & $\begin{array}{l}\text { May function in membrane trafficking. Exhibits calcium- } \\
\text { dependent phospholipid binding properties. }\end{array}$ \\
\hline 16 & $\begin{array}{l}\text { Ubiquitin-conjugating enzyme } \\
\text { E2N }\end{array}$ & UBE2N & P61088 & 17006.63 & 6.18 & 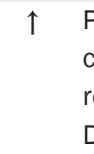 & $\begin{array}{l}\text { Plays a role in the control of progress through the cell } \\
\text { cycle and differentiation. Plays a role in the error-free DNA } \\
\text { repair pathway and contributes to the survival of cells after } \\
\text { DNA damage. }\end{array}$ \\
\hline
\end{tabular}

\section{Bioinformatics analysis of effectors after endothelial NNAs activation}

After comprehensive analysis of the effects of acetylcholine receptor agonists on endothelial cells (Table 6), we found that acetylcholine, which can activate non-neuronal nicotinic and muscarinic receptors, down-regulated Destrin expression in endothelial cells, and oxotremorine, which can activate the non-neuronal muscarinic receptors but not the non-neuronal nicotinic receptors, had a similar effect. However, neither pilocarpine, which cannot activate non-neuronal nicotinic or muscarinic receptors, nor nicotine, another acetylcholine receptor agonist that only activates non-neuronal nicotinic receptors, could induce changes to Destrin expression. These results suggested that Destrin might have a relationship to 
Table 3. List of differentially expressed proteins found in the most significant network $12 \mathrm{~h}$ after oxotremorine treatment using Ingenuity Pathway Analysis (Figure 1B1-1B3). The proteins were identified by 2-DE and LC-MS. The spots identified by 2-DE are indicated with a corresponding number on the gel ( $\uparrow$, the protein up-regulated; $\downarrow$, the protein down-regulated).

\begin{tabular}{|c|c|c|c|c|c|c|c|}
\hline $\begin{array}{l}\text { Spot } \\
\text { № }\end{array}$ & Protein name & $\begin{array}{c}\text { Gene } \\
\text { names }\end{array}$ & Accession & $\mathrm{Mw}(\mathrm{kDa})$ & $p l$ & Change & Protein function \\
\hline \multirow[t]{2}{*}{1} & Isoform 1 of pyridoxal kinase & PDXK & 000764 & 35102.3 & 5.75 & R & $\begin{array}{l}\text { Required for synthesis of pyridoxal-5-phosphate from } \\
\text { vitamin B6. }\end{array}$ \\
\hline & $\begin{array}{l}\text { Guanine nucleotide-binding protein } \\
G(I) / G(S) / G(T) \text { subunit beta-1 }\end{array}$ & GNB1 & P62873 & 7245.77 & 5.6 & $\begin{array}{l}G \\
\mathrm{a} \\
\mathrm{tr}\end{array}$ & $\begin{array}{l}\text { Guanine nucleotide-binding proteins (G proteins) } \\
\text { are involved as a modulator or transducer in various } \\
\text { transmembrane signaling systems. }\end{array}$ \\
\hline 3 & Destrin & DSTN & P60981 & 18374.53 & 8.12 & $\begin{array}{l}\text { A } \\
(\mathrm{P} \\
\mathrm{p}\end{array}$ & $\begin{array}{l}\text { Actin-depolymerizing protein. Severs actin filaments } \\
\text { (F-actin) and binds to actin monomers (G-actin). Acts in a } \\
\text { pH-independent manner. }\end{array}$ \\
\hline 5 & Annexin A5 & ANXA5 & P08758 & 35805.58 & 4.94 & $\begin{array}{l}\text { T } \\
\text { ir } \\
\text { W }\end{array}$ & $\begin{array}{l}\text { This protein is an anticoagulant protein that acts as an } \\
\text { indirect inhibitor of the thromboplastin-specific complex, } \\
\text { which is involved in the blood coagulation cascade. }\end{array}$ \\
\hline 6 & $\begin{array}{l}\text { Serine/threonine-protein kinase } \\
\text { 38-like }\end{array}$ & STK38L & Q9Y2H1 & 53871.65 & 6.38 & Ir & $\begin{array}{l}\text { Involved in the regulation of structural processes in } \\
\text { differentiating and mature neuronal cells. }\end{array}$ \\
\hline 7 & $\begin{array}{l}\text { ADP-ribosylation factor-like protein } \\
3\end{array}$ & ARL3 & P36405 & 20324.33 & 6.94 & $\begin{array}{l}\text { S } \\
\text { ir }\end{array}$ & $\begin{array}{l}\text { Small GTP-binding protein which cycles between an } \\
\text { inactive GDP-bound and an active GTP-bound form. }\end{array}$ \\
\hline 8 & 14-3-3 Protein epsilon & YWHAE & P62258 & 29173.9 & 4.63 & $\begin{array}{l}\text { A } \\
\mathrm{s} \\
\mathrm{p} \\
\mathrm{re} \\
\mathrm{B} \\
\mathrm{O}\end{array}$ & $\begin{array}{l}\text { Adapter protein implicated in the regulation of a large } \\
\text { spectrum of both general and specialized signaling } \\
\text { pathway. Binds to a large number of partners, usually by } \\
\text { recognition of a phosphoserine or phosphothreonine motif. } \\
\text { Binding generally results in the modulation of the activity } \\
\text { of the binding partner. }\end{array}$ \\
\hline
\end{tabular}

non-neuronal muscarinic receptor effects. Acetylcholine, oxotremorine, and nicotine were able to induce changes in the expression of FKBP1A, but pilocarpine could not affect it. These results suggested that FKBP1A might be related to the downstream effects of non-neuronal acetylcholine receptors. Nicotine, an agonist of non-neuronal nicotinic receptors, induced expression changes of MIF and Profilin-1 in endothelial cells. This result suggested that MIF and Profilin-1 might be the effectors of non-neuronal nicotinic receptors. However, we found two spots (spot 1 and spot 3 in Table 5) that were both identified as Profilin-1, but the expression changes were in different directions. This result was unexpected and needs further validation. Pilocarpine affected the expression of MIF and Profilin-1, which was also affected by nicotine. This result suggested that there might be a new target of pilocarpine on endothelial cells. This target might be similar to the non-neuronal nicotinic receptors (Table 6).

\section{Confirmation of protein expression differences using Western blotting analysis}

To corroborate the expression data derived from proteomic analysis between the control group and the acetylcholine receptor agonist treatment group, Western blotting was conducted against four proteins: Destrin, FKBP1A, MIF, and Profilin-1 (Figure 3). The Western blots showed the same trend as the proteomic analyses did. Regarding the confusing spots, the results showed that nicotine up-regulated Profilin-1 expression in endothelial cells, validating the result of spot 3 (Table 5).

\section{Discussion}

Cardiovascular disease remains the most common cause of death in the developed world and is predicted to kill 20 million people worldwide each year until at least 2015 according to the World Health Organization ${ }^{[21]}$. Endothelial dysfunction 
Table 4. List of differentially expressed proteins found in the most significant network $12 \mathrm{~h}$ after pilocarpine treatment using Ingenuity Pathway Analysis (Figure 1C1-1C3). The proteins were identified by 2-DE and LC-MS. The spots identified by 2-DE are indicated with a corresponding number on the gel ( $\uparrow$, the protein up-regulated; $\downarrow$, the protein down-regulated).

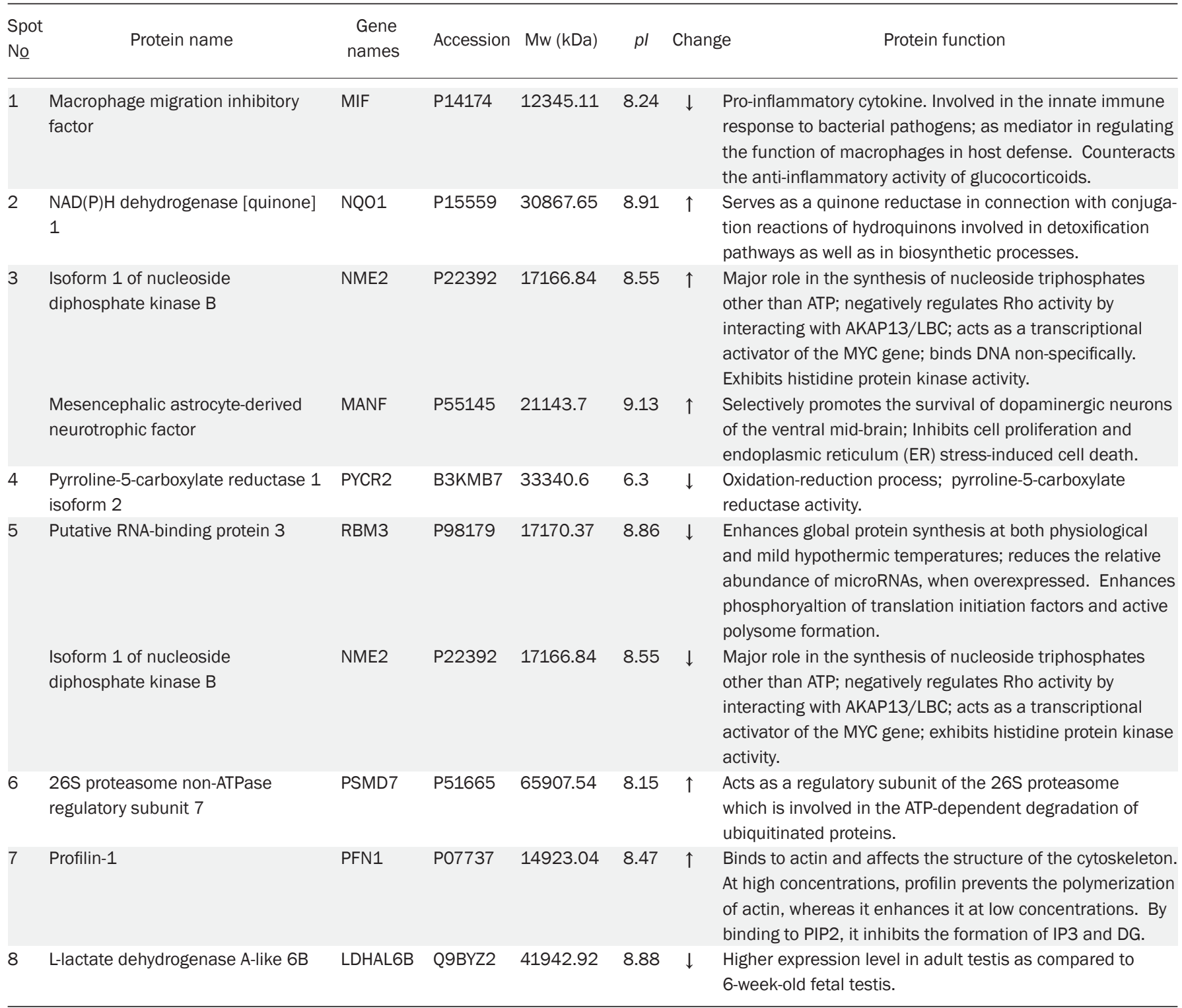

is responsible for many cardiovascular diseases, such as atherosclerosis, hypertension, and hyperlipidemia ${ }^{[2,3]}$. Proteomics technologies are rapidly evolving and provide the opportunity to identify and characterize protein profiles of samples at different time and conditions. Many studies have applied proteomics technologies to endothelial cells to investigate cardiovascular disease. In this study, we investigated the effects of four different types of acetylcholine receptor agonists in endothelial cells by comparing the altered protein profiles between the control group and the treatment group that was treated with acetylcholine, oxotremorine, pilocarpine or nicotine at the pharmacological concentration of $10 \mu \mathrm{mol} / \mathrm{L}$ for $12 \mathrm{~h}$. We identified 16, 9, 8 and 9 protein spots in the groups that were separately treated with acetylcholine, oxotremorine, pilocarpine or nicotine. According to the characteristics of the four types of agonist, we focused our attention on Destrin, FKBP1A, MIF and Profilin-1. Destrin might have a relationship with non-neuronal muscarinic receptor effects; FKBP1A might be related to non-neuronal acetylcholine receptor effects; and MIF and Profilin-1 might be the effectors of nonneuronal nicotinic receptors. Pilocarpine affected the expression of MIF, and Profilin-1 expression patterns suggested that there might be a new target of pilocarpine on endothelial cells and that it might behave similarly to non-neuronal nicotinic receptors.

Destrin is known to regulate actin dynamics by enhancing the depolymerization of F-actin into G-actin and promoting filament severing ${ }^{[22,23]}$. Remodeling of the actin cytoskeleton 
Table 5. List of differentially expressed proteins found in the most significant network $12 \mathrm{~h}$ after nicotine treatment using Ingenuity Pathway Analysis (Figure 1D1-1D3). The proteins were identified by 2-DE and LC-MS. The spots identified by 2-DE are indicated with a corresponding number on the gel ( $\uparrow$, the protein up-regulated; $\downarrow$, the protein down-regulated).

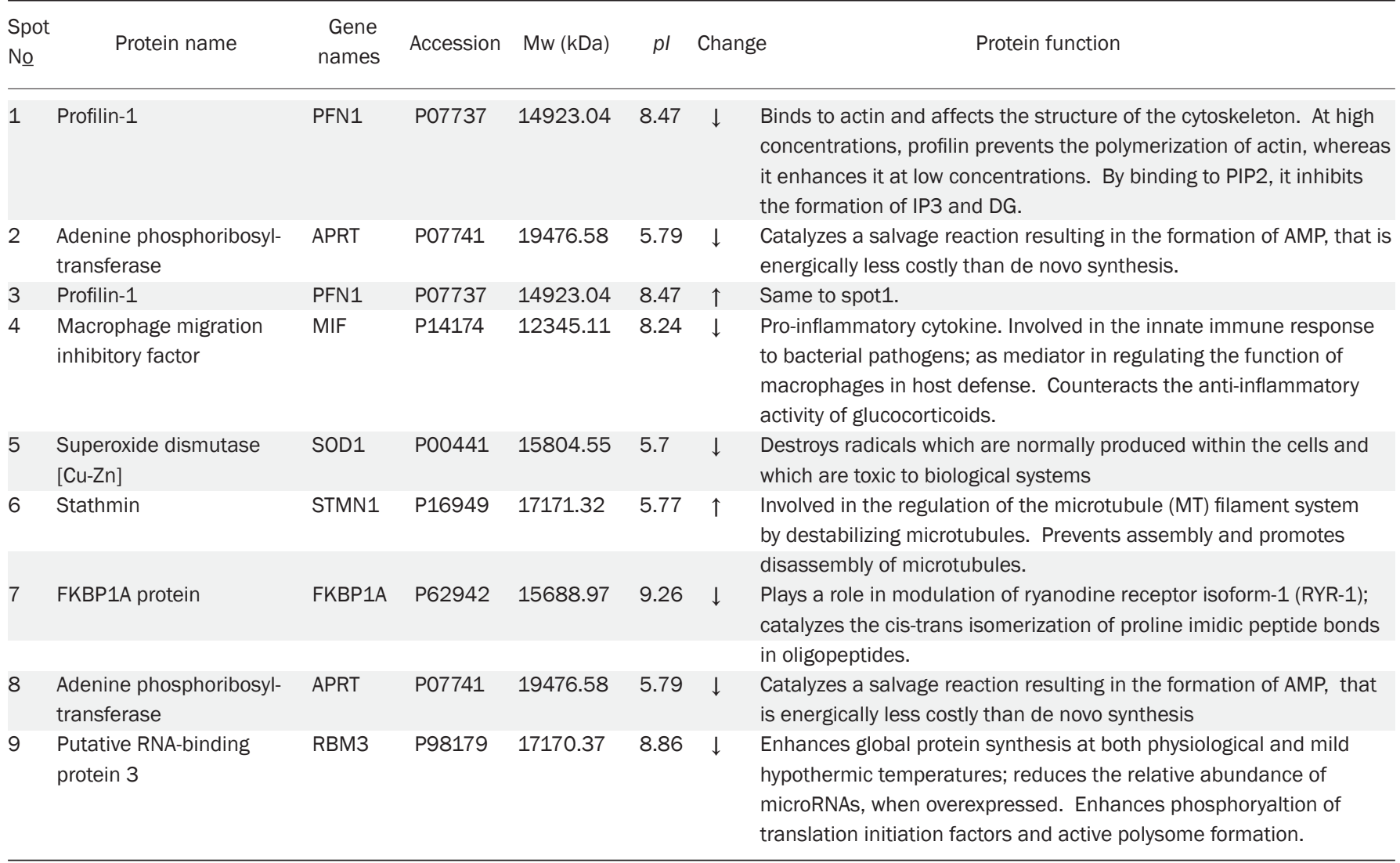

Table 6. Analysis of endothelial non-neuronal acetycholine receptors effectors.

\begin{tabular}{lcccc}
\hline Drug & Destrin & FKBP1A & MIF & Profilin-1 \\
\hline ACh & + & + & - & - \\
Oxo & + & + & - & - \\
Pilo & - & - & + & + \\
Nico & - & + & + & + \\
\hline
\end{tabular}

ACh, Acetylcholine; Oxo, Oxotremorine; Pilo, Pilocarpine; Nico, Nicotine; NNMR, non-neuronal muscarinic receptor; NNNR, non-neuronal nicotinic receptor. +, activation; -, no activation.

through actin dynamics is essential for numerous basic biological processes, including cell polarization, contractile force generation, cell migration, cell division, endocytosis and exocytosis $^{[24-27]}$. In addition to its structural role, the status of the actin cytoskeleton has been shown to affect a diverse array of intracellular signaling processes. Destrin belongs to the actinbinding proteins ADF (actin-depolymerizing factor)/cofilin family, which participate in the actin-dependent vesicular trafficking of postsynaptic receptors ${ }^{[28]}$. Postsynaptic regulation of receptors by vesicular trafficking is an important basic mechanism of synaptic plasticity, and actin plays a key role in this process. ADF/cofilin-mediated actin dynamics regulate the vesicular trafficking of acetylcholine receptors in space and time and the targeting of acetylcholine receptors to cell surfaces of neonatal postsynaptic sites ${ }^{[2,30]}$. Compared with the passive diffusion mechanism, active transport mechanisms play a more important role in the vesicular trafficking of acetylcholine receptors from cluster generation to redistribution to the postsynaptic sites. In this process, $\mathrm{ADF} /$ cofilin may be the first to localize in generating sites to regulate the actin cytoskeleton local dynamic positioning and to assist in maintaining vesicle fusion and acetylcholine receptors in recycling. $\mathrm{ADF} /$ cofilin can thus more quickly transport cell signals, such as acetylcholine, into cells and play the messenger function, thereby further triggering cell polarization and migration. In this study, we found that acetylcholine and oxotremorine, agonists of non-neuronal muscarinic receptors, affected Destrin expression in endothelial cells. This is the first report that Destrin may have a relationship with non-neuronal muscarinic receptor effectors, which may be helpful in explaining the role of non-neuronal muscarinic receptors in slowing the atherosclerosis progress.

FKBP1A, also known as FKBP12, belongs to the immunophilin protein family, which plays a role in immunoregula- 
A
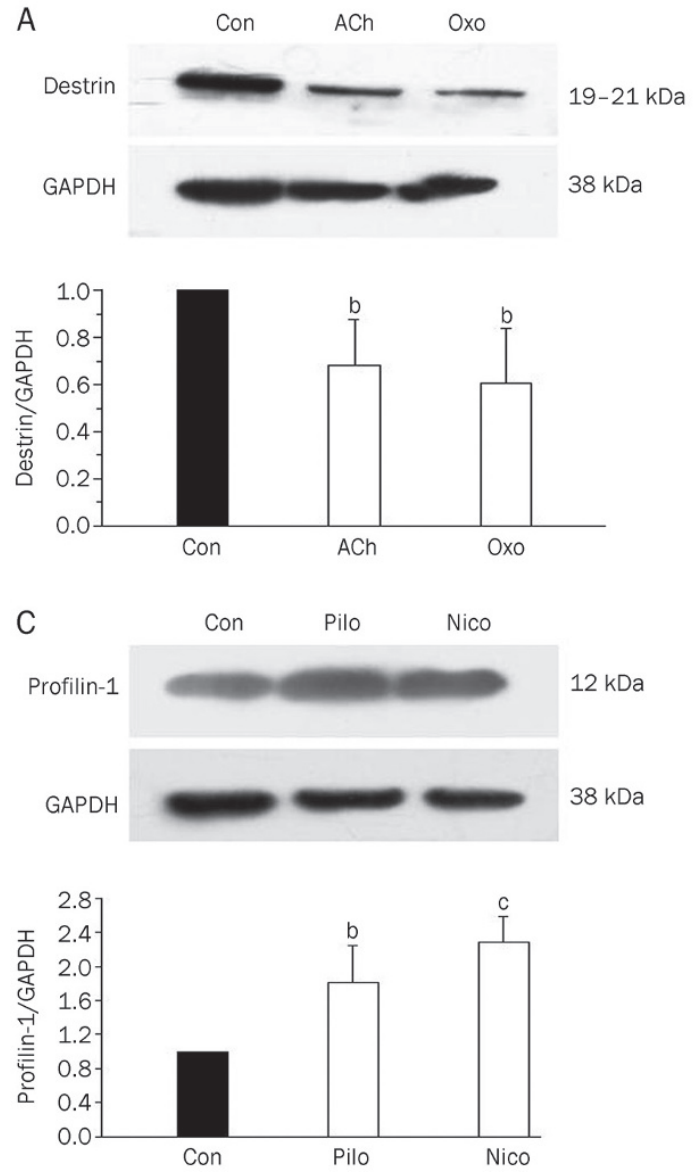
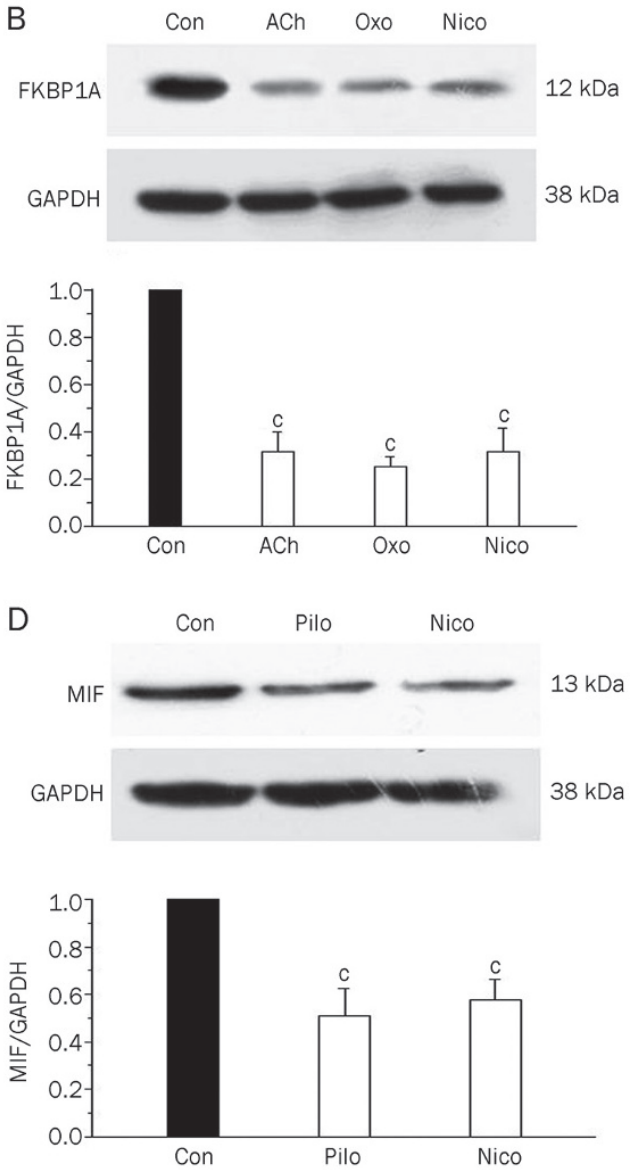

Figure 3. Western blotting was performed to corroborate the results derived from proteomic analysis. The Western blots show that Destrin decreased when the cells were treated with acetylcholine or oxotremorine (A); FKBP1A decreased when the cells were treated with acetylcholine, oxotremorine or nicotine (B); Profilin-1 increased when the cells were treated with pilocarpine or nicotine (C); MIF decreased when the cells were treated with pilocarpine or nicotine (D). GAPDH was used to normalize protein loading. Values are expressed as the mean \pm SD. $n=3 .{ }^{b} P<0.05,{ }^{c} P<0.01$ vs control.

tion and basic cellular processes involving protein folding and trafficking. FKBP1A interacts with several intracellular signal transduction proteins including the type I TGF-beta receptor and also plays a role in intracellular calcium regulation by associating with three types of calcium release channel complexes, cardiac and skeletal ryanodine receptors and the inositol 1,4,5-trisphosphate receptor ${ }^{[31-33]}$. In endothelial cells, nonneuronal muscarinic receptors are $\mathrm{G}$ protein-coupled receptors, which bind extracellular signal molecules of this signaling pathway, activate phospholipase C (PLC- $\beta$ ) on the plasma membrane, cause hydrolysis from 4,5-phosphatidylinositol bisphosphate (PIP2) into 1,4,5-trisphosphate (IP3) and diacylglycerol (DG), and the conversion of extracellular signals into intracellular signals. IP3 binds to the endoplasmic reticulum IP3 ligand-gated calcium channels, which open calcium channels, and causes the increase of intracellular the $\mathrm{Ca}^{2+}$ level, and regulates the secretion of $\mathrm{NO}$ and vascular contraction and relaxation. In the present study, we found that acetylcholine, oxotremorine and nicotine induced expression changes of FKBP1A but pilocarpine did not affect FKBP1A expression. This result suggested that FKBP1A might be related to non- neuronal acetylcholine receptor effectors. Therefore, the nonneuronal acetylcholine system, which can induce calcium release through the IP3 pathway, and further influence the secretion of $\mathrm{NO}$ in endothelial cells, might be regulated by FKBP1A.

MIF (Macrophage migration inhibitory factor), encoded by the MIF gene, is a structurally unique cytokine, which is a critical mediator of acute and chronic inflammatory diseases such as atherosclerosis, septic shock, Crohn's disease and rheumatoid arthritis ${ }^{[34-38]}$. MIF plays its role in influencing the regulation of macrophages in the host defense function by suppressing the anti-inflammatory effects of glucocorti$\operatorname{coids}^{[399]}$. Contrary to its historically based name, MIF has been recognized to exhibit chemokine-like properties ${ }^{[40,41]}$ and is corroborated as a non-cognate ligand of the chemokine receptors CXCR2 and CXCR4. MIF is highly expressed in different types of macrophages and endothelial cells in atherosclerotic plaques, which suggests that it is closely associated with atherosclerosis, and functional studies established the contribution of MIF to lesion progression and plaque inflammation ${ }^{[42]}$. Studies have shown that non-neuronal nicotinic receptors are 
involved in angiogenesis during many pathological processes such as inflammation, ischemia, cancer and atherosclerosis, so that the protein is very important for the study of endothelial cells non-neuronal nicotinic receptors in inflammation and atherosclerosis. Profilin-1, which belongs to the fiber protein family, is an actin monomer binding protein which is encoded by PFN1 genes. A role for Profilin-1 in promoting actin filament formation has been suggested by several studies in lots of organisms ${ }^{[43]}$. Overexpression of Profilin-1 in a human endothelial cell line indicate potential roles for Profilin-1 in stabilizing dynamic actin filaments or directing filament assembly ${ }^{[44]}$, and its silence can inhibit endothelial cell proliferation and migration. Profilin-1 serves as an essential regulator of hypertension and atherosclerosis ${ }^{[45,46]}$. In the current study, we found that nicotine, an agonist of non-neuronal nicotinic receptors, induced expression changes of MIF and Profilin-1 in endothelial cells. This suggested that MIF and Profilin-1 might be the effectors of non-neuronal nicotinic receptors. Pilocarpine affected the expression of MIF and Profilin-1, which was also affected by nicotine, suggesting that there might be a new target of pilocarpine on endothelial cells. This target might be similar to non-neuronal nicotinic receptors. Therefore, the MIF and Profilin-1 signaling pathway has a very significant role in the study of the non-neuronal acetylcholine system and the discovery of new drug targets.

In conclusion, we used the 2-DE proteomic approach with highly sensitive mass spectrometry to analyze changes in the protein expression of HUVECs induced by cholinergic agonists. Although it would not be scrupulous to declare that we had characterized all the protein changes after stimulation of NNAs, it was not possible to comment here on all the detected proteins that had remarkable changes. The above examples were sufficient enough to manifest that our experiments revealed some proteins that were directly associated with cell function and the subsequent cellular signal transduction pathway of non-neuronal acetylcholine receptors. It appears that Destrin might be a non-neuronal muscarinic receptors effector; FKBP1A might be an effector of non-neuronal acetylcholine receptors; and MIF and Profilin-1 might be associated with the activation of non-neuronal nicotinic receptors. Pilocarpine regulation of the expression of MIF and Profilin-1 suggested that there might be a new target of pilocarpine on endothelial cells that is similar to non-neuronal nicotinic receptors. Further study should be performed to facilitate understanding of non-neuronal acetylcholine receptors.

\section{Perspectives}

The non-neuronal acetylcholine system in endothelial cells plays a physiological/pathophysiological role in regulating endothelial function, vascular tone, angiogenesis, and inflammation. However, the identity of the mediators of intracellular signal transduction in endothelial cells after stimulation of the non-neuronal acetylcholine system remains unclear. In the current study, we analyzed the underlying effectors after cholinergic agonist activation of the non-neuronal acetylcholine system in cultured human umbilical vein endothelial cells.
The identification of the differentially expressed proteins Destrin, FKBP1A, MIF, and Profilin-1 provided new clues toward further study of the influences of non-neuronal acetylcholine system activation on endothelial function in cardiovascular diseases.

\section{Acknowledgements}

The present study was supported by grants from the State Key Research Project of China (AWS11J003) and Tianjing Key Technologies Research and Development Program, China (05ZHGCGX01300).

\section{Author contribution}

Hai WANG designed the research; Yuan-yuan ZHANG, Wei SHEN, Wen-yu CUI, Yan-fang ZHANG, and Chao-liang LONG performed the research; Yuan-yuan ZHANG, Liancheng ZHANG, and Zhi-yuan PAN analyzed the data and wrote the paper.

\section{Abbreviations}

2-DE, two-dimensional gel electrophoresis; ACh, acetylcholine; DTT, Dithiothreitol; FKBP1A, FK506 binding protein 1a; HUVEC, human umbilical vein endothelial cells; LC-MS, liquid chromatography-mass spectrometry; MIF, macrophage migration inhibitory factor; Nico, nicotine; NNAs, non-neuronal acetylcholine system; NNMR, non-neuronal muscarinic receptors; Oxo, oxotremorine; Pilo, pilocarpine; SDS-PAGE, sodium dodecyl sulfate (SDS)-Polyacrylamide gel electrophoresis.

\section{References}

1 Triggle CR, Samuel SM, Ravishankar S, Marei I, Arunachalam G, Ding H. The endothelium: influencing vascular smooth muscle in many ways. Can J Physiol Pharmacol 2012; 90: 713-38.

2 Butt M, Dwivedi G, Blann A, Khair O, Lip GY. Endothelial dysfunction: methods of assessment \& implications for cardiovascular diseases. Curr Pharm Des 2010; 16: 3442-54.

3 Grassi D, Desideri G, Ferri C. Cardiovascular risk and endothelial dysfunction: the preferential route for atherosclerosis. Curr Pharm Biotechnol 2011; 12: 1343-53.

4 Evora PR, Evora PM, Celotto AC, Rodrigues AJ, Joviliano EE. Cardiovascular therapeutics targets on the NO-sGC-cGMP signaling pathway: a critical overview. Curr Drug Targets 2012; 13: 1207-14.

5 Lee R, Channon KM, Antoniades C. Therapeutic strategies targeting endothelial function in humans: clinical implications. Curr Vasc Pharmacol 2012; 10: 77-93.

6 Wang Y, Zeng FH, Long CL, Pan ZY, Cui WY, Wang RH, et al. The novel ATP-sensitive potassium channel opener iptakalim prevents insulin resistance associated with hypertension via restoring endothelial function. Acta Pharmacol Sin 2011; 32: 1466-74.

7 Wessler I, Kirkpatrick CJ. Acetylcholine beyond neurons: the nonneuronal cholinergic system in humans. Br J Pharmacol 2008; 154: 1558-71.

8 Kawashima K, Fujii T. Basic and clinical aspects of non-neuronal acetylcholine: overview of non-neuronal cholinergic systems and their biological significance. J Pharmacol Sci 2008; 106: 167-73.

9 Kirkpatrick CJ, Bittinger F, Nozadze K, Wessler I. Expression and function of the non-neuronal cholinergic system in endothelial cells. 
Life Sci 2003; 72: 2111-6.

10 Furchgott RF, Zawadzki JV. The obligatory role of endothelial cells in the relaxation of arterial smooth muscle by acetylcholine. Nature 1980; 288: 373-6.

11 Lee J, Cooke JP. The role of nicotine in the pathogenesis of atherosclerosis. Atherosclerosis 2011; 215: 281-3.

12 Inanaga K, Ichiki T, Miyazaki R, Takeda K, Hashimoto T, Matsuura $\mathrm{H}$, et al. Acetylcholinesterase inhibitors attenuate atherogenesis in apolipoprotein E-knockout mice. Atherosclerosis 2010; 213: 52-8.

13 Yu M, Chen DM, Hu G, Wang H. Proteomic response analysis of endothelial cells of human coronary artery to stimulation with carbachol. Acta Pharmacol Sin 2004; 25: 1124-30.

14 Shan LM, Wang $\mathrm{H}$. Pharmacological characteristics of the endothelial target for acetylcholine induced vascular relaxation. Life Sci 2002; 70: 1285-98.

15 Shi CG, Hu G, Wang $H$. Protective effect of arecoline on expression of inflammatory molecules in endotheial cells injuried by oxLDL. Chin J Cardiol 2004; 32: 650.

16 Duan ZB, Wang H. Regulation effect of arecoline on excess expression of adhesive molecules in endothelial cells injuried with high concentration of $D$-glucose. Chin J Clin Pharmacol Ther 2006; 11: 27-32.

17 Duan ZB, Wang H. Protective effect of compounds on endothelial cells injuried with homocysteine. Chin Pharm Bull 2006; 22: 537-42.

18 Pandey A, Mann M. Proteomics to study genes and genomes. Nature 2000; 405: 837-46.

19 Panpac DI, Shahrokh Z. Mass spectrometry innovations in drug discovery and development. Pharm Res 2001; 18: 131-45.

20 Gharahdaghi F, Weinberg CR, Meagher DA, Imai BS, Mische SM. Mass spectrometric identification of proteins from silver-stained polyacrylamide gel: a method for the removal of silver ions to enhance sensitivity. Electrophoresis 1999; 20: 601-5.

21 Edwards AVG, White MY, Cordwell SJ. The role of proteomics in clinical cardiovascular biomarker discovery. Mol Cell Proteomics 2008; 7: 1824-37.

22 Carlier MF, Laurent V, Santolini J, Melki R, Didry D, Xia GX, et al. Actin depolymerizing factor (ADF/cofilin)enhances the rate of filament turnover: implication in actin-based motility. J Cell Biol 1997; 136: 1307-22.

23 McGough A, Pope B, Chiu W, Weeds A. Cofilin changes the twist of F-actin: implications for actin filament dynamics and cellular function. J Cell Biol 1997; 138: 771-81.

24 Ayscough KR. In vivo functions of actin-binding proteins. Curr Opin Cell Biol 1998; 10: 102-11.

25 Bamburg JR. Proteins of the ADF/cofilin family: essential regulators of actin dynamics. Annu Rev Cell Dev Biol 1999; 15: 185-230.

26 Pollard TD, Blanchoin L, Mullins RD. Molecular mechanisms controlling actin filament dynamics in nonmuscle cells. Annu Rev Biophys Biomol Struct 2000; 29: 545-76.

27 Abe H, Nagaoka R, Obinata T. Cytoplasmic localization and nuclear transport of cofilin in cultured myotubes. Experimental Cell Res 1993; 206: 1-10.

28 Lee CW, Han J, Bamburg JR, Han L, Lynn R, Zheng JQ. Regulation of acetylcholine receptor clustering by ADF/cofilin-directed vesicular trafficking. Nat Neurosci 2009; 12: 848-56.

$29 \mathrm{Fu} \mathrm{H}$, Subramanian RR, Masters SC. 14-3-3 proteins: structure, function, and regulation. Annu Rev Pharmacol Toxicol 2000; 40: 617-47.

30 Gohla A, Bokoch GM. 14-3-3 regulates actin dynamics by stabilizing phosphorylated cofilin. Curr Biol 2002; 12: 1704-10.

31 Bultynck G, De Smet P, Rossi D, Callewaert G, Missiaen L, Sorrentino $\mathrm{V}$, et al. Characterization and mapping of the $12 \mathrm{kDa}$ FK506-binding protein (FKBP12)-binding site on different isoforms of the ryanodine receptor and of the inositol 1,4,5-trisphosphate receptor. Biochem J 2001; 354: 413-22.

32 Bultynck G, Rossi D, Callewaert G, Missiaen L, Sorrentino V, Parys JB, et al. The conserved sites for the FK506-binding proteins in ryanodine receptors and inositol 1,4,5-trisphosphate receptors are structurally and functionally different. J Biol Chem 2001; 276: 47715-24.

33 MacMillan D, Currie S, Bradley KN, Muir TC, McCarron JG. In smooth muscle, FK506-binding protein modulates IP3 receptor-evoked $\mathrm{Ca}^{2+}$ release by mTOR and calcineurin. J Cell Sci 2005; 118: 5443-51.

34 Yildirim MA, Goh KI, Cusick ME, Barabasi AL, Vidal M. Drug target network. Nat Biotechnol 2007; 25: 1119-26.

35 Calandra T, Roger T. Macrophage migration inhibitory factor: a regulator of innate immunity. Nat Rev Immunol 2003; 3: 791-800.

36 Mitchell RA, Bucala R. Tumor growth-promoting properties of macrophage migration inhibitory factor (MIF). Semin Cancer Biol 2000; 10 : 359-366.

37 Morand EF, Leech M, Bernhagen J. MIF: a new cytokine link between rheumatoid arthritis and atherosclerosis. Nat Rev Drug Discov 2006; 5: 399-410.

38 Zernecke A, Bernhagen J, Weber C. Macrophage migration inhibitory factor in cardiovascular disease. Circulation 2008; 117: 1594-602.

39 Rhen T, Cidlowski JA. Antiinflammatory action of glucocorticoids--new mechanisms for old drugs. New Engl J Med 2005; 353: 1711-23.

40 Bernhagen J, Krohn R, Lue H, Gregory JL, Zernecke A, Koenen RR, et al. MIF is a noncognate ligand of CXC chemokine receptors in inflammatory and atherogenic cell recruitment. Nat Med 2007; 13: 587-96.

41 Kamir D, Zierow S, Leng L, Cho Y, Diaz Y, Griffith J, et al. A Leishmania ortholog of macrophage migration inhibitory factor modulates host macrophage responses. J Immunol 2008; 180: 8250-61.

42 Schober A, Bernhagen J, Weber C. Chemokine-like functions of MIF in atherosclerosis. J Mol Med (Berl) 2008; 86: 761-70.

43 Yah J, Hearer BK. Profilin-1 is required for the normal timing of actin polymerization in response to thermal-stress. FEBS Lett 1996; 398: 303-7.

44 Theriot JA, Mitchison TJ. The faces of profilin. Cell 1993; 75: 835-8. 45 Moustafa-Bayoumi M, Alhaj MA, El-Sayed O, Wisel S, Chotani MA, Abouelnaga ZA, et al. Vascular hypertrophy and hypertension caused by transgenic overexpression of profilin 1. J Biol Chem 2007; 282: 37632-9.

46 Romeo GR, Moulton KS, Kazlauskas A. Attenuated expression of profilin-1 confers protection from atherosclerosis in the LDL receptor null mouse. Circ Res 2007; 101: 357-67. 